TECHNICAL TRANSACTIONS 4/2018

MECHANICS

DOI: $10.4467 / 2353737$ XCT.18.066.8378 SUBMISSION OF THE FINAL VERSION: 9/3/2018

\author{
Pawel Lempa (plempa@ialab.cs.kitami-it.ac.jp) \\ Michal Ptaszynski \\ Fumito Masui \\ Department of Computer Science Kitami Institute of Technology, Japan
}

\title{
THE USE OF GENETIC ALGORITHM TO OPTIMIZE QUANTITATIVE
}

LEARNER'S MOTIVATION MODEL

WYKORZYSTANIE ALGORYTMU GENETYCZNEGO DO OPTYMALIZACJI

ILOŚCIOWEGO MODELU MOTYWACJI UCZNIA

\begin{abstract}
The paper presents a method of optimizing Quantitative Learner's Motivation Model with the use of genetic algorithm. It is focused on optimizing the formula for prediction of learning motivation by means of different weights for three values: interest, usefulness in the future and satisfaction. For the purpose of this optimization, we developed a C++ library that implements a genetic algorithm and an application in $\mathrm{C} \#$ which uses that library with data acquired from questionnaires enquiring about those three elements. The results of the experiment showed improvement in the estimation of student's learning motivation.
\end{abstract}

Keywords: optimization, genetic algorithm, Quantitative Learner's Motivation Model

\section{Streszczenie}

W artykule przedstawiono metodę optymizacji ilościowego modelu motywacji ucznia z wykorzystaniem algorytmu genetycznego. Przedstawiona metoda polega na optymalizacji formuly przewidywania motywacji do nauki poprzez wykorzystanie różnych wag dla trzech różnych wartości: zainteresowanie przedmiotem, jego przydatność w przyszłości i zadowolenie zudziału w zajęciach. Na potrzebę optymalizacji stworzono bibliotekę C++, która implementuje algorytm genetyczny oraz aplikację w C\#, która wykorzystuje tę bibliotekę razem z zebranymi danymi z ankiet $\mathrm{w}$ celu indukcji powyższych trzech elementów. Wyniki eksperymentu wykazaly poprawę w szacowaniu motywacji uczniów.

Słowa kluczowe: optymalizacja, algorytm genetyczny, ilościowy model motywacji ucznia 


\section{Introduction}

A genetic algorithm (GA) is an algorithm which looks for the best solution using heuristic searching based on natural selection of chromosomes known in genetics [10]. This approach has proven its utility in many cases, as it sometimes replaced other tools used in artificial intelligence, and was also often applied together with them to resolve a given research problem.

Quantitative Lerner's Motivation Model (QLMM) is a composition of three elements, which represent the attitude of students towards the attended courses. Quantification of those elements represents the general level of learning motivation. The three elements called interest, usefulness in the future, and satisfaction in original model have the same level of importance. However, experience shows that they are not equally important. Therefore, in this research we decided to perform an optimization experiment to find the best weights for these three elements.

For the experiment, we used two pieces of software. The first was the one used in Nobuta et al. [1], made for calculation of QLMM, which we modified by adding settable values of the weights for interest, usefulness, and satisfaction. The second software used our own library of Genetic Algorithm to find the best weights for the three values applied in QLMM.

For the optimization purpose, we used four types of genetic algorithms. The simple genetic algorithm, GA with limited lifetime of chromosomes, GA with sexual selection in reproduction and algorithm with both limited lifetime and sexual selection.

\section{Related Research}

There has been a number of research on applying Genetic Algorithm (GA) in various optimization tasks.

In language generation, an example of GA use was presented in the paper by Montero and Araki (2007) [3], where they described a method based on a random selection of a small number of phrases from a database, in which the genetic algorithm generated and evaluated trivial dialogue phrases. Another example is a creation of sophisticated texts like poetry described in [4] and in [5], where a genetic algorithm was used to find a solution that satisfies the constraints of grammaticality and meaningfulness or a story generator [7], where GA was used in a story planer to find space of possible stories because it greatly reduced the risk of getting stuck in the local optima.

In dialogue systems, an example of using Genetic Algorithm with Sexual selection was used by Araki and Kuroda (2006) [6]. Due to the use of this type of GA, a system in its initial state could be trained to sufficient level without any prior language information, like vocabulary or grammar.

\section{Quantitative Learner's Motivation Model}

Quantitative Lerner's Motivation Model (QLMM) [1] is composed of three elements representing the attitude of students towards the attended courses. Quantification of those elements represents the general level of learning motivation. These three elements are as 
follows: interest, usefulness in the future and satisfaction. Each element corresponds to the points of view included in the ARCS model [14, 15].

A detailed description of the three basic elements of the model is presented below:

- Interest - contains elements reflecting the generally perceived interest and attention paid by the learners to the contents of the course and corresponds to "attention" in the ARCS model,

- Usefulness in the future - represents the potential to contribute to the improvement of the skills and knowledge possessed by the learners themselves and corresponds to "relevance" in the ARCS model,

- Satisfaction - contains the elements reflecting the expectations toward the class at the beginning of the course or the satisfaction of the course at the end of the school year and corresponds to "satisfaction" in the ARCS model.

\section{Genetic Algorithm}

To perform the optimization, a Simple Genetic Algorithm (SGA) was used at first [8]. In this algorithm, the chromosomes $(\mathrm{v}(\mathrm{t}))$ were used in the floating-point form, with a crossover:

$$
\begin{aligned}
& v_{1}(t)=v_{1}(t-1) a_{1}+\left(1-a_{1}\right) v_{2}(t-1) \\
& v_{2}(t)=v_{2}(t-1) a_{2}+\left(1-a_{2}\right) v_{1}(t-1)
\end{aligned}
$$

where:

$a_{1}, a_{2}$ - random numbers in the range [0..1], and the mutation is in the form:

$$
v(t)=\mathrm{a} v(t-1)
$$

For the selection of the size of the population, a solution has been proposed [9] in which the number of chromosomes of the population is a variable depending on the value of the evaluation function of entire population. This helps to avoid the situation in which too small population of solutions could lead to a convergence to the local optimum, and too high population to a significant increase in the calculation time. It is also assumed that, at different stages of evolution, the optimal number of population may be different. Because this parameter of chromosome age has been inserted, which is an integer in the range [0..max age], where max age is the maximum age of a chromosome and after exceeding it, chromosome will not be taken into account in further calculations. After each iteration of the algorithm, the age is increased by 1 , while during the selection - chromosomes with higher age than the maximum are rejected. In this situation, there is no need to define the selection algorithm because the age of a chromosome is determined by the objective function. The age of a chromosome determines which chromosomes will take part in the creation of new solutions. In the calculation of the lifetime of a chromosome, a linear assignment was used in the following form:

$$
\operatorname{Min} L T+(\operatorname{MaxLT}-\operatorname{Min} L T) \frac{\operatorname{eval}\left(v_{i}(t)\right)-A b s F i t M i n}{A b s F i t M a x-A b s F i t M i n}
$$


where:

MinLT - minimum possible age of a chromosome,

MaxLT - maximum possible age of a chromosome, $\operatorname{eval}\left(v_{\mathrm{i}}\right)$ - value of the adaptation function of a chromosome,

AbsFitMin - the lowest value of the adaptation function found during all previous iterations, AbsFitMax - the largest value of the adaptation function found during all previous iterations.

\section{Experiment}

The data used for the experiments was collected from questionnaires for nine different courses for undergraduate students of $1^{\text {st }}$ to $3^{\text {rd }}$ year in the Kitami Institute of Technology. There were 5,040 answers collected at the beginning and at the end of the school year. Range values for the three elements of QLMM were from 1 to 5.

For the experiment, we used two pieces of software. The first one, written in C\#, was developed previously for the quantification of learner's motivation [1]. The only change was made for adding settable values of weights for the three values of QLMM. The second software, written in C\#, used our own library of Genetic Algorithm made in C++ [11]. The function of the second software was finding the best weights for QLMM. The diagram of the solution is showed in Fig. 1.

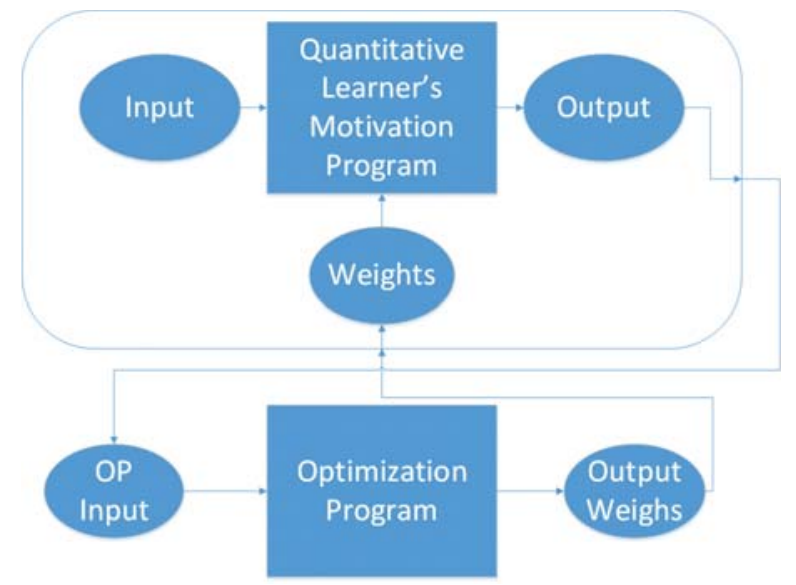

Fig. 1. Diagram of the solution

Solution steps:

1) Uploading data from excel files containing questionnaire answers to a program

2) Calculating QLMM in the first program without any weights for interest, usefulness in the future and satisfaction

3) Uploading results from the first program to the second

4) Calculating weights for the three elements of QLMM with the use of genetic algorithm

5) Calculating QLMM again in the first program with weights received from the second program

6) Uploading results from the first to the second program again 
7) Repeating steps 4 to 6 until the end of all generations of used GA

We used four different types of genetic algorithms for optimization. The basic one was a simple genetic algorithm (SGA). The second algorithm used the limited lifetime of chromosomes. The third one was SGA with sexual selection in reproduction [12]. The last algorithm used both solutions used in the second and third type of GA. All of them had the same starting parameters.

- The type of representation: floating point,

- Crossover: 2-point, with a probability: 0:9,

- The probability of mutation: $0: 1$,

- The size of population: 100 ,

- The number of algorithm iterations: 2000.

All the results were compared to the output from basic program without optimization of the weights. All four solutions showed improvement in relation to original results. In Table 1, we showed the percentage values of improvement of precision and recall.

Table 1. Improvement in results after optimization with GA

\begin{tabular}{|c|c|c|}
\hline Genetic algorithm type & Improvement in Precision & Improvement in Recall \\
\hline Simple Genetic Algorithm (SGA) & $6 \%$ & $7 \%$ \\
\hline GA with limited lifetime & $13 \%$ & $15 \%$ \\
\hline GA with sexual selection & $11 \%$ & $11 \%$ \\
\hline $\begin{array}{c}\text { GA with limited lifetime and sexual } \\
\text { selection }\end{array}$ & $17 \%$ & $21 \%$ \\
\hline
\end{tabular}

\section{Conclusions}

The paper presented a method of optimizing Quantitative Learner's Motivation Model with the use of different types of a genetic algorithm. For the experiments, we used data collected from questionnaires for undergraduate students. In the experiments, the program based on the research of QLMM used weights calculated in a separate program which used different types of a genetic algorithm to find optimal weights for interest, usefulness and satisfaction from QLMM. All the four solutions resulted in improvements of precision and recall used for the calculation of optimization of motivation model. The best solution was reached by means of the genetic algorithm with sexual selection in reproduction of chromosomes and their limited lifetime. The way of using a program allows for reusing it after a proper adjustment in other research for optimization of, e.g., binary classifiers [13]. In future, we are planning to use this solution in the optimization of sentiment analysis, fake reviews detection, cyberbullying detection and others from the natural language processing field. 


\section{References}

[1] Nobuta Y., Masui F., Ptaszynski M, Modeling Learning Motivation of Students Based on Analysis of Class Evaluation Questionnaire, Technical Transactions, 2-M/2015, 193-201.

[2] Ekbal, A., Saha, S., Simultaneous feature and parameter selection using multiobjective optimization: application to named entity recognition International Journal of Machine Learning and Cybernetics, Volume 7, Issue 4, 2016, 597-611.

[3] Calkin S. Montereo, Araki K., Unsupervised language independent genetic algorithm approach to trivial dialogue phrase generation and evaluation. Lecture Notes in Computer Science, Springer, Berlin, Heidelberg, Vol. 4592, 2007, 388-394.

[4] Manurung R., Ritchie G., Thompson H., Using Genetic Algorithms to Create Meaningful Poetic Text, Journal of Experimental \& Theoretical Artificial Intelligence, Vol. 24, Issue 1, 2012, 43-64.

[5] Manurung H.M., An evolutionary algorithm approach to poetry generation, Doctoral Thesis, Institute for Communicating and Collaborative Systems, School of Informatics University of Edinburgh, 2003.

[6] Araki K., Kuroda M., Generality of Spoken Dialogue System using SeGA-IL for Different Languages, Systems and Computers in Japan, Vol. 35, No. 12, 2004.

[7] McIntyre N., Lapata M., Plot Induction and Evolutionary Search for Story Generation, Proceedings of the $48^{\text {th }}$ Annual Meeting of the Association for Computational Linguistics, Stroudsburg, 2010, 1562-1572.

[8] Goldberg D.E., Holland J.H.., Genetic algorithms and machine learning, Machine learning 3(2), 1988, 95-99.

[9] Langdon WB, Poli R. Foundations of genetic programming, Springer, 2002.

[10] Melanie M. An introduction to genetic algorithms, Cambridge, Massachusetts London, England, Fifth printing 1999.

[11] Ladd SR. Genetic algorithms in C++, Hungry Minds, Incorporated, 1995.

[12] Deslauriers W.A., Asexual Versus Sexual Reproduction in Genetic Algorithms, Carleton University.

[13] Wu Ch. H., Tzeng G.H., Goo Y.J., Fang W.C., A real-valued genetic algorithm to optimize the parameters of support vector machine for predicting bankruptcy, Expert Systems with Applications, 2007, Vol. 32, Issue 2, 397-408.

[14] Keller J.M., Kopp T., Application of the ARCS model of motivational design, M. Reigluth (Ed.), Instructional theories in action: Lessons illustrating selected theories and models, Lawrence Erlbaum Associates, USA 1987.

[15] Keller J.M., Suzuki K., Use of the ARCS motivation model in courseware design (Chapter 16), [in:] D.H. Jonnasen (Ed.), Instructional designs for microcomputer courseware, Lawrence Erlbaum Associates, USA 1988. 